\title{
Pengaruh Nilai Tukar Uang, Jumlah Uang Beredar dengan Kegiatan Export Terhadap Inflasi Pada Masa Pandemic Covid-19
}

\author{
Suginam $^{1}$, Elmira Siska ${ }^{2, *}$, Syahrijal Hidayat ${ }^{3}$ \\ ${ }^{1}$ Prodi Manajemen Retail, Universitas Budi Darma, Medan, Indonesia \\ ${ }^{2}$ Prodi Manajemen, Fakultas Ekonomi dan Bisnis, Universitas Bina Sarana Informatika, Jakarta, Indonesia \\ ${ }^{3}$ Prodi Akuntansi, STIE Muhammadiyah Asahan, Asahan, Indonesia \\ Email: ${ }^{1}$ suginam.icha@gmail.com, ${ }^{2,}{ }^{*}$ elmira.ems@ @si.ac.id, ${ }^{3}$ syahrijalhidayat528@gmail.com \\ Email Penulis Korespondensi: elmira.ems@bsi.ac.id \\ Submitted: 06/11/2021; Accepted: 12/11/2021; Published: 30/11/2021
}

\begin{abstract}
Abstrak-Covid-19 mengakibatkan banyaknya perubahan dan gejolak ekonomi sebuah negara menjadi sangat sulit dan juga sangat mempengaruhi perdagangan dunia, pada penelitian ini melihat beberapa pengaruh nilai tukar uang dollar dalam bentuk rupiah dan jumlah uang yang beredar dipasar dunia yang memiliki hubunan dengan kegiatan expor textile pada masa pandemic hal-hal tersebut dihubungkan dengan pengaruh terhadap inflasi dimana inflasi merupakan keadaan yang menentukan harga barang-barang dalam negara meingkat maupun menurun, dampak yang diperlihatkan antara variabel bebas terhadap variabel terikat dalam hubungan berpengaruh secara langsung atau tidak, hasil dari penelitian ini adalah
\end{abstract}

Kata Kunci: Nilai Tukar; Peredaran Uang; Expor dan Inflasi

\begin{abstract}
Covid-19 causes many changes and economic turmoil of a country to be very difficult and also greatly affects world trade, this study looks at some of the effects of the dollar exchange rate in the form of rupiah and the amount of money circulating in the world market which is related to textile export activities. during the pandemic these things are associated with the effect on inflation where inflation is a condition that determines the price of goods in the country increases or decreases, the impact shown between the independent variables on the dependent variable in a direct or indirect effect relationship, the results of this study are.
\end{abstract}

Keywords: Exchange Rate; Money Circulation; Exports and Inflation

\section{PENDAHULUAN}

Perkembangan perdagangan ekonomi dunia secara global sedang mengalami krisis yang sangat parah hal tersebut terjadi dikarenakan adanya pandemic covid-19. Efek yang tampak pada masa pandemic covid-19 mengakibatkan banyaknya perusahaan yang mengalami kesulitan dalam pengoperasian dan produktifitas sebuah perusahaan. Kebijakan pemerintah untuk melarang aktifitas yang menimbulkan kerumunan dan keramaian juga salah satu faktor sulitnya sebuah perusahaan berproduksi dan menyebabkan kebangkrutan dan memutuskan perjanjikan kerja secara sepihak dan besar-besaran. Hal tersebut tidak hanya terjadi di Indonesia bahkan diseluruh negara-negara besar (Astriani et al., n.d.).

Dampak tersebut juga terasa sangat kuat di Indonesia yang menyebabkan banyaknya dan bertambahnya jumlah pengangguran. Hal tersebut mempengarhi pertumbuhan ekonomi yang semakin melemah, hal tersebut dapat berdamak meningkatnya angka kemiskinan dan bisa berdampak lebih buruk lagi seperti meningkatnya angka kematian karena kelaparan dan meningkatnya kriminalitas dalam sebuah negara(Yunus \& Rezki, 2020).

Dampak kemiskian dapat juga diartikan keadaan ekonomi sebuah negara tidak stabil sehingga dapat mempengaruhi kegiatan ekspor antar negara. Nilai komoditas ekspor di Indonesia mulai dari tahun 2016 sampai degan tahun 2020 mengalami naik dan turun menyentuh nilai "USD11,87 miliar, kemudian di 2017 menyentuh USD12,59 miliar dengan surplus USD 5 miliar, pada tahun 2018 nilai ekspor sebesar USD13,27 miliar dan di tahun 2019 total ekspor industri tekstil dan produk tekstil ini turun 2,87\% menjadi US\$ 12,84 miliar" hingga saat ini media menyatakan meningkatnya kegiatan ekspor negara Indonesia dan menyokong kestabilan ekonomi bangsa. Dalam kestabilan perekonomian Indonesia sering terjadi naik turun harga pasar bahkan mengalami krisis moneter misalnya saja inflasi (Sofie \& Putri, 2020).

Inflasi sendiri merupakan suatu proses yang disebutkan sebagai dampak dari naiknya harga barang-barang secara umum dan merata. Naiknya inflasi merupakan acaman terhadap meningkatnya angka kemiskinan dan menuru krisis moneter sebuah negara, adanya inflasi juga menyebabkan timbulnya bahaya sosial dan keamanan sebuah negara, sehingga inflasi harus ditekankan agar tidak terjadi kenaikan. Naiknya inflasi dapat diakibatkan oleh beberapa faktor salah satunya hal penyebab terbanyak adalah ketidakseimbangan antara ketersediaan barang dan uang. Badan pusat statistik negara Indonesia mengatakan pandemic Covid-19 membuat perekonomian indonesia gonjang gannjing dan menganggu pola inflasi di Indonesia juga.

Hal tersebut terjadi berhubungan juga dengan nilai tukar rupiah yaitu nilai mata uang Indonesia dalam bentuk rupiah dimata negara lain misalnya nilai tukar rupiah dengan mata uang negara lain seperti rupiah ke Yen mata uang China, rupiah ke Lira mata uang turkiye maupun rupiah terhadap dolar Amerika. Saat ini dunia menggunakan mata uang Dolar Amerika sebagai mata uang acuan dunia dalam urusan transaksi. Saat ini mata uang amerika terus meningkat karena terjadinya penggunaan dan kebutuhan terhadap dolar semakin tinggi dalam sebuah negara tetapi dolar juga dapat mengalami naik turun 
nilai tukar mata uangnya tergantung kepada tingkat kesadaran dan penanganan masyarakat terhadap dolar (Keršulienė et al., 2018)i.

Pada peneitian terdahulu proses ekspor juga terkait kepada pengukuran nilai tukar uang suatu negara terhadap nilai tukar Indonesia dan pengaruh terhadap inflasi dipengaruhi dengan kuat dengan sistem dan target ekspor. Pada penelitian lainnya menunjukan nilai terhadap eksopr memilihi hubungan variabel negative sementara nila turkar uang mendapatkan hasil yang positif (Desmond Lim, Jessy Valencia, 2021).

Penelitian terdahulu menyatakan "Bertambahnya surplus produksi yang ditandai dengan pertumbuhan PDB juga akan mendorong naiknya ekspor karena kelebihan output domestik akan disalurkan melalui ekspor" hasil yang didapatkan terdapat penaruh positif terhadap penekanan nilai inflasi (Sofie \& Putri, 2020). Penelitian terdahulu lainnya menyatakan mendapatkan hasil nilai tukar terhadap rupiah dengan dolar memiliki hubungan sigifikansi dan jumlah mata uang yang beredar tidak memiliki pengaruh yang signifikan terhadap inflasi (Wendy, 2020).

Pada penelitian ini ingin melihat hubungan antara variabel bebas seperti nilai tukar, jumlah uang beredar, ekspor terhadap variabel terikat yaitu inflasi pada masa pandemic Covid-19.

\section{METODE PENELITIAN}

Metodologi penelitian ini digunakan dengan cara menerapkan metode analisis deskriptif untuk menganalisa pengaruh nilai tukar, jumlah uang beredar, dan ekspor terhadap tingkat inflasi pada masa pandemic covid-19. Pada analisa menggunakan pengujian dilakukan pendekatan non-parametrik melainkan mengunakan analisis pengujian linear regresi berganda. Sumber data yang digunakan pada penelitian ini merupakan data dari sumber skunder dimana data merupakan kumpulan dari datadata yang sudah ada dari beberapa sumber data yaitu data primer dan juga data skunder. Dan tahapan pengumpulan data dilakukan proses studi pustaka dari beberapa sumber data pemerintahan, media, dan situs web, dokumentasi(Albi Anggito \& Johan Setiawan, 2018).

\subsection{Teknik Analisa Data}

Pada teknik analisa data dilakukan pengujian secara menyeluruh yang biasa disebut dengan uji asumsi klasik dimana uji ini terdiri dari beberapa pengujian sebagai berikut ini (Aren \& Nayman Hamamci, 2020):

1. Uji normalitas

Uji normalitas merpakan tahapan pengujian yang dilakukan untuk mengetahui data yang diuji memili data yang normal yang dilakukan dalam pengujian regresi hasil yang dapat digunakan dapat melalui gamar grafik histogram, pada grafik akan tampak data observasi dengan data residual tampak mendekati distribusi tidak normal atau distribusi normal. pada tahapan pengujian lain dapat dilakukan dengan cara melihat Unstandardized Residual pada nilai yang lebih besar dari 0,05

2. Uji multikolinearis.

Pada uji multikolinearis memperlihatkan hasil sebuah data terindikasi sebuah data mengalami gejaa multikolinearis dari hasil yang di dapat merupakan pertanda apakah sebuah data mengalami penyimpangan pada uji asumsi klasik.

3. Uji heterokedastisitas

Uji heterokedastisitas merupakan pengujian yang dilakukan untuk mengetahui apakah sebuah data terjadi kecenderungan dan kemiripan antara satu data dengan data yang lain, pada proses dan hasil pengujian ini bertujuan untuk melihat data terhadap hasil grafik tidak adanya penumpukan data dalam sebuah kasus tertentuk.

\subsection{Teknik pengujian}

Teknik pengujian pada tahapan penelitian ini menggunakan pengujian hipotesis dalam melihat masing-masing relasi dimana hubungan variabel bebas dengan variabel terikat. Adapun pengujia yang dilakukan secara berkala uji hipotesis T dan uji hipotesis F untuk melihat signifinaksi antara masig-masing hubungan variabel yang ada(Okagbue et al., 2021).

\subsection{Nilai Tukar Rupiah}

Nilai tukar rupiah merupakan nilai diterapkan terhadap uang dalam hal pembayaran atau proses transaksi sekarang maupun dimasa yang akan mendatang nilai tukar uang juga dikenal sebagai kurs yaitu salah satu yang dapat mempengaruhi sitem dan tatanan ekonomi suatu negara. Nilai rupiah dipatokan berdasarkan nilai tukar dollar yang menjadi mata uang pusat central dunia dan digunakan oleh banyak negara. Semakin banyak minat penukaran mata uang sebuah negara makan semakin tinggi nilai mata uang sebuah negara (Sebo \& Nafi, 2021).

Ketidakstabilan nilai terhadap nilai tukar rupiah dapat menyebakan harga saham mengalami ketidakstabilan juga dan juga menjajdi penyebab menurunnya Kinerja bursa efek. Nilai tukar dapat berubah-ubah berdasarkan peningkatan permintaan uang dalam sebuah transaksi dunia, tingkat permintaan kerja, berhubungan dengan ekpor dan impor. Hal tersebut telah diatur dan diwaspadai oleh pihak terkait dalam sebuah managemen bang central suatu negara

\subsection{Jumlah Uang Beredar}


Jumlah uang beredar merupakan suatu uang yang telah diedarkan dan disebarluaskan oleh bank central dengan ketentuan yang telah disetarakan yang telah diakumulasikan dengan uang giral dari perorangan, perusahaan, dan juga pemerintahan dan jenis uang sebagai berikut ini (Rumondor et al., 2021):

a. Uang kartal

Merupakan uang yang berbentuk logam, kertas dan berlaku dalam edaran

b. Uang giral

Merupakan uang dalam bentuk giro maupun dalam bentu cek

c. Uang kuasi

Merupakan jenis uang yang memiliki masa dalam jangka panjang atau untuk masa yang akan mendatang seperti valuta asing milik swasta, tabungan dan deposito.

\subsection{Kegiatan Ekspor}

Kegiatan ekspor merupakan suatu kegiatan transaksi yang dilakukan dengan cara mengirimkan barang yang besaral dari daerah langsung atau dari dalam negeri yang akan dikirim keluar negeri atau negara lain. Sistem yang digunakan dalam prose transaksi pada masa dan era teknologi dapat dilakukan dengan mudah menggunakan sistem e-commerce dan transaksi uang dapat dilakukan dengan e-pay atau via bank (Sofie \& Putri, 2020).

\subsection{Inflasi}

Inflasi merupakan proses naiknya harga barang secara umum dan merata dan bukan hanya menaikan harga barang saja tetapi juga dapat menaikan harga jasa. Inflasi yang terus meningkat dapat menyebabkan kehancuran dan ketidakstailan ekonomi suatu negara. Kenaikan suatu nilaii atau harga barang maupun jasa yang naik satu persatu atau barang tertentu saja tidak dapat disebut dengan inflasi, tetapi ketika harga barang secara menyeluruh berganti menjadi lebih tinggi dan inflasi dapat saja berubah kapan saja dan banyak penyebab terjadinya inflasi. Hal tersebut dapat dikatakan sebagai tahapan menurunnya nilai mata uang sebuah negara (Rumondor et al., 2021).

\section{HASIL DAN PEMBAHASAN}

Hasil pada pembahasan ini merupakan nilai yang dihitung berdasarkan data dan hasil responden yang diolah menggunakan aplikasi statistic SPSS dengan tahapan pengujian asumsi klasik hingga penarikan hipotesis menggunakan regresi linear dengan pengujian $\mathrm{T}$ dan pengujian $\mathrm{F}$ bersadarkan ukuran dan aturan statistic yang berlaku menggunakan $\mathrm{t}$ dan $\mathrm{f}$ tabel.

\subsection{Uji Asumsi Klasik}

1. Uji multikolinearitas

Pada pengujian ini data tidak disebutkan teridentifikasi multikolinearitas yang dapat mempengaruhi hasil pengujian dengan syarat nilai VIF harus memiliki jumlah lebih kecil dari 10 atau $(<10)$ dan cara kedua dapat dilihat sebuah data tidak teridentifikasi multikolinearitas jika nilai tolerance lebih besar dari 0,10. Berikut merupakan tabel Collinearity Statistics yang memiliki hasil tolerance dan VIF. Pada data tabel 1 di bawah tampak nilai tolerance seluruh variabel bebas lebih besar dari 0,10 atau $(>0,10)$ yaitu hasil dari nilai variabel nilai tukar uang sebesar 0.522 , hasil dari variabel bebas uang beredar sebesar 0,518 dan pada variabel ekspor sebesar 0,986 dan seluruh nilai VIF yang dimiliki oleh masingmasing variabel bebas $<10$ yaitu $1.917,1.929$, dan 1.015 sehingga jelas data bebas dari multikolinearitas.

Tabel 1. Uji multikolinearitas

\begin{tabular}{|c|c|c|c|c|c|c|c|c|}
\hline \multicolumn{9}{|c|}{ Coefficients $^{\mathrm{a}}$} \\
\hline \multirow{2}{*}{\multicolumn{2}{|c|}{ Model }} & \multicolumn{2}{|c|}{$\begin{array}{l}\text { Unstandardized } \\
\text { Coefficients }\end{array}$} & \multirow{2}{*}{$\begin{array}{c}\text { Standardized } \\
\text { Coefficients } \\
\text { Beta } \\
\end{array}$} & \multirow[t]{2}{*}{$\mathrm{t}$} & \multirow[t]{2}{*}{ Sig. } & \multicolumn{2}{|c|}{ Collinearity Statistics } \\
\hline & & $\mathrm{B}$ & Std. Error & & & & Tolerance & VIF \\
\hline \multirow[t]{4}{*}{1} & (Constant) & 10.456 & 3.360 & & 3.112 & .003 & & \\
\hline & Nilai Tukar Uang & 2.077 & .146 & .087 & .527 & .600 & .522 & 1.917 \\
\hline & Uang Beredar & 1.155 & .173 & .148 & .895 & .374 & .518 & 1.929 \\
\hline & Ekspor & 1.175 & .137 & .154 & 1.279 & .205 & .986 & 1.015 \\
\hline & lent Variable: INFA & & & & & & & \\
\hline
\end{tabular}

2. Uji Normalitas

Uji normalitas dapat diketahui dengan melihat dari gambar 2, dimana data yang disebut normal jika mengikuti garis horizontal dan tidak menyimpang membentuk garis lainnya, pada gambar berikut tampak data teridentifikasi sebagai data yang sudah normal. dalam mengukur normalitas sebuah data juga dapat dilakukan dengan cara melakukan pengujian Kolmogorov dimana nilai harus lebih besar dari 0,05 pada nilai asymp sig. (2-tailed). Pada gambar tampak hasil sebesar 0,200 dimana data dinyatakan normal. 
Ekonomi, Keuangan, Investasi dan Syariah (EKUITAS)

Vol 3, No 2, November 2021, Hal 33-38

ISSN 2685-869X (media online)

DOI 10.47065/ekuitas.v3i2.1032

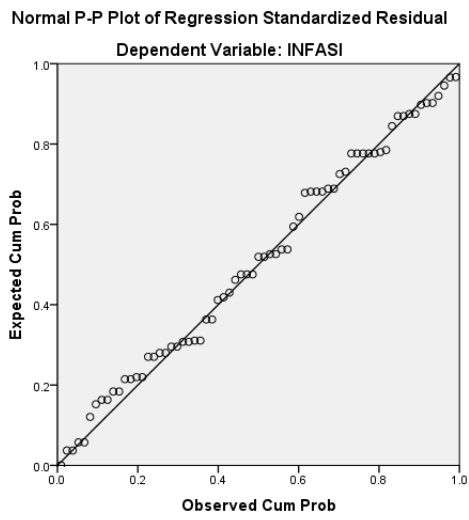

Gambar 1. Uji normalitas

Pengujian normalitas lainnya sebagai berikut ini:

Tabel 2. Uji normalitas Kolmogorov

\begin{tabular}{llr}
\hline \multicolumn{2}{c}{ One-Sample Kolmogorov-Smirnov Test } & $\begin{array}{c}\text { Unstandardized } \\
\text { Residual }\end{array}$ \\
\hline $\mathrm{N}$ & & 69 \\
Normal Parameters ${ }^{\mathrm{a}, \mathrm{b}}$ & Mean & .0000000 \\
& Std. Deviation & 1.18983829 \\
Most Extreme Differences & Absolute & .074 \\
& Positive & .056 \\
& Negative & -.074 \\
Test Statistic & & .074 \\
Asymp. Sig. (2-tailed) & & $.200^{\mathrm{c}, \mathrm{d}}$ \\
\hline
\end{tabular}

3. Uji Heterokedastisitas

Pada uji ini dapat dilihat pada gambar sebuah plot dimana jika titik-titik menyebar baik di atas maupun dibawah dan titik tersebut membentuk pola tertentu sehingga data tidak teridentifikasi heterokedastisitas. Terlihat pada gambar dibawah ini:

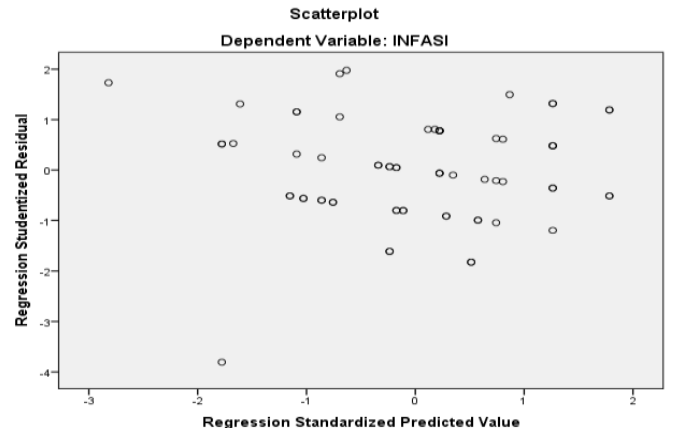

Gambar 2. Uji Heterokedastisitas

\subsection{Uji Regresi Linear Berganda}

Tabel 3. Regresi Linear berganda

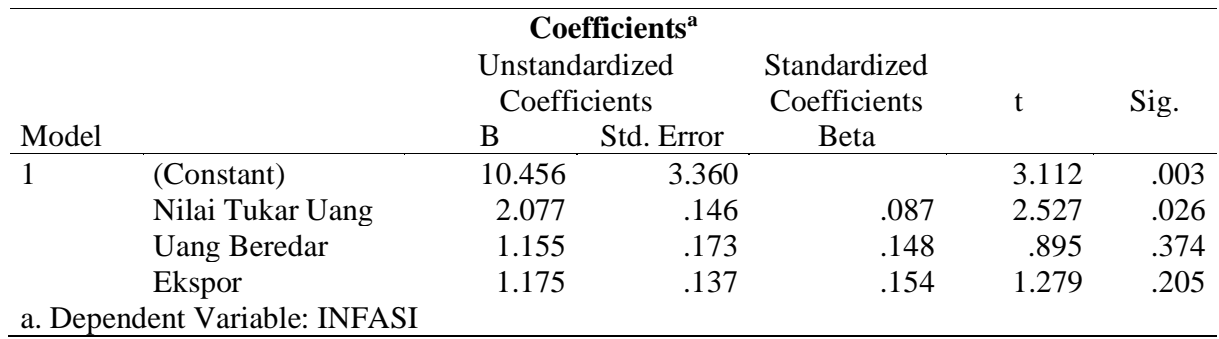


Pada tabel 3 memiliki persamaan regresi $Y=10.456+2.0779(\mathrm{X} 1)+1.155(\mathrm{X} 2)+1.175(\mathrm{X} 3)$ yang berarti keseluruhan variabel bebas atau variabel independent yaitu variabel X1(nilai tukar uang), X2 ( Uang beredar), X3 (Ekspor) tehadap Y atau inflasi sebagai memiliki nilai koefisien positif yaitu nilai tukar uang 2,077 berarti memiliki pengaruh positif terhadap Y atau inflasi dengan jumlah hasil kenaikan 2,077. Variabel uang beredar memiliki nilai 1,155 terhadap $Y$ atau inflasi memiliki nilai pengaruh positif dengan jumlah hasil yang sama yaitu 1,155 dan variabel kegiatan ekpor juga memiliki pengaruh positif terhadap inflasi suatu negara dengan besaran nilai 1,175 dimana kenaikan terhadap pengaruh sebesar nilai yang sama juga.

\subsection{Uji Hipotesis}

Pada pengujian ini dilihat dari pengaruh masing-masing tabel antara $t_{\text {tabel }}$ dengan $t_{\text {hitung }}$ dan $F_{\text {tabel }}$ dengan $F_{\text {hitung }}$ adapun syarat dalam membaca pengujian $F$ hasil diapat diketahui dengan melakukan perbandingan hasil uji dalam Anova $F_{\text {tabel }}=\mathrm{f}(\mathrm{k} ; \mathrm{n}-\mathrm{k})=$ $F(4 ; 69-4)=F(4 ; 65)$ sehingga pada tabel $f$ dilihat data urutan ke empat baris ke 65 berarti nilai tabel $f$ untuk jumlah responden sebanyak 69 dengan 4 variabel sebesar 2,51.

Pada tabel $\mathrm{t}_{\text {tabel }} \mathrm{t}(\mathrm{a} / 2 ; \mathrm{n}-\mathrm{k}-1)$ yang berarti $\mathrm{t}(0,025 ; 69-4-1)$ adalah $\mathrm{t}(0,025 ; 64)$ yang dilihat pada tabel 0,025 baris ke 64 adalah 1,997 nilai pada thitung harus lebih besar dari tabel sehingga dinyatakan nilai merupakan nilai diterima jika tidak maka hipotesis terhadap pengaruh kepada inflasi ditolak.

Tabel 4. Uji Hipotesis

\begin{tabular}{llrrrr}
\hline & \multirow{2}{*}{ Model } & \multicolumn{2}{c}{ Uji T } & \multicolumn{2}{c}{ Uji F } \\
& \multicolumn{1}{c}{ t } & Sig. & t & Sig. \\
\hline 1 & (Constant) & 3.112 & .003 & & \\
& Nilai Tukar Uang & 2.527 & .026 & & \\
& Uang Beredar & .895 & .374 & 3.753 & $.004^{\mathrm{b}}$ \\
& Ekspor & 1.279 & .205 & & \\
\hline
\end{tabular}

a. Dependent Variable: INFASI

Maka dapat ditarik kesimpulan pada data di atas:

1. Hasil dari keseluruhan uji f tampak memiliki nilai 3,753 > dari nilai $F_{\text {tabel }}$ sehingga dapat disimpulkan seluruh data variabel independent memiliki pengaruh signifikansi terhadap variabel dependent dengan nilai positif dan hasil dapat di simpulkan $\mathrm{H}_{0}$ di teriman dan $\mathrm{H}_{\mathrm{a}}$ diterima oleh seluruh variabel.

2. Pada variabel $X 1$ tampak memiliki nilai 2,527 dimana nilai lebih besar dari $t_{\text {tabel }}$ sebesar 1,997 sehingga nilai tukar uang sangat berpengaruh signifikansi terhadap inflasi $(\mathrm{Y})$ dimana $\mathrm{H}_{0}$ di terima dan $\mathrm{H}_{\mathrm{a}}$ diterima dan pengaruh bernilai positif.

3. Pada variabel $\mathrm{X} 2$ tampak memiliki nilai 0,895 dimana nilai lebih kecil dari $t_{\text {tabel }}$ sebesar 1,997 sehingga uang beredar berpengaruh signifikansi terhadap inflasi $(\mathrm{Y})$ dimana $\mathrm{H}_{0}$ ditolak dan $\mathrm{H}_{\mathrm{a}}$ diterima pengaruh bernilai positif.

4. Pada variabel X3 tampak memiliki nilai 1,279 dimana nilai lebih kecil dari tabel sebesar 1,997 sehingga ekspor berpengaruh signifikansi terhadap inflasi $(\mathrm{Y})$ dimana $\mathrm{H}_{0}$ ditolak dan $\mathrm{H}_{\mathrm{a}}$ diterima pengaruh bernilai positif.

\section{KESIMPULAN}

Berdasarkan hasil dari kesimpulan terlihat secara simultan dan keseluruhan masing-masing variabel baik nilai tukar uang, uang beredar dan ekspor memiliki pengaruh yang signifikansi, pada data yang sangat mempengaruhi terjadinya kenaikan inflasi yaitu minat tukar uang atau kebutuhan uang menjadi potensi utama terhadap inflasi lalu ekspor dengan nilai mendekati diterima secara keseluruhan, uang beredar memiliki pengaruh lebih sedikit dari variabel lainnya terhadap pengaruh atau tidaknya pada terjadinya inflasi.

\section{REFERENCES}

Albi Anggito, \& Johan Setiawan. (2018). Metodologi Penelitian Kuantitatif (E. L. Deffi (ed.)). CV Jejak.

Aren, S., \& Nayman Hamamci, H. (2020). Relationship between risk aversion, risky investment intention, investment choices: Impact of personality traits and emotion. Kybernetes, 49(11), 2651-2682. https://doi.org/10.1108/K-07-2019-0455

Astriani, L., Mulyanto, T. Y., Bahfen, M., \& Dityaningsih, D. (n.d.). Meningkatkan Ekonomi Masyarakat Melalui Produk Kreatif dari Pengolahan Sampah Plastik.

Desmond Lim, Jessy Valencia, N. dan W. C. (2021). Pengaruh Kegiatan Ekspor Di Era Covid-19 Terhadap Produk Domestik Bruto Tahun 2020. 1, 521-527.

Keršulienė, V., Zavadskas, E. K., \& Turskis, Z. (2018). Selection of Rational Dispute Resolution Method By Applying New Step-Wise Weight Assessment Ratio Analysis (Swara). Journal of Business Economics and Management, 11(2), 243-258. https://doi.org/10.3846/jbem.2010.12

Okagbue, H. I., Oguntunde, P. E., Obasi, E. C. M., \& Akhmetshin, E. M. (2021). Trends and usage pattern of SPSS and Minitab Software in Scientific research. Journal of Physics: Conference Series, 1734, 012017. https://doi.org/10.1088/1742-6596/1734/1/012017

Rumondor, N., Kumaat, R. J., \& ... (2021). Pengaruh Nilai Tukar Dan Jumlah Uang Beredar Terhadap Inflasi Di Indonesia Pada Masa Pandemic Covid-19. Jurnal Berkala Ilmiah ..., 21(03), 57-67. https://ejournal.unsrat.ac.id/index.php/jbie/article/view/36177 
Ekonomi, Keuangan, Investasi dan Syariah (EKUITAS)

Vol 3, No 2, November 2021, Hal 33-38

ISSN 2685-869X (media online)

DOI 10.47065/ekuitas.v3i2.1032

Sebo, S. S., \& Nafi, M. (2021). Pengaruh Inflasi, Nilai Tukar, Suku Bunga, Dan Volume Transaksi Terhadap Harga Saham Perusahaan Pada Kondisi Pandemi Covid-19. Jurnal Akuntansi Dan Perpajakan, 6(2), 113-126. https://doi.org/10.26905/ap.v6i2.5358

Sofie, V., \& Putri, K. (2020). Pengaruh Nilai Tukar Dan Produk Domestik Bruto Terhadap Ekspor Textile Dengan Inflasi Sebagai Variabel Intervening. Business and Economics Conference in Utilization of Modern Technology, 3, 585-599.

Wendy, S. (2020). Universitas bung hatta padang. IV(3), 1-11.

Yunus, N. R., \& Rezki, A. (2020). Kebijakan Pemberlakuan Lock Down Sebagai Antisipasi Penyebaran Corona Virus Covid-19. SALAM: Jurnal Sosial Dan Budaya Syar-I, 7(3). https://doi.org/10.15408/sjsbs.v7i3.15083 